Sains Malaysiana 51(1)(2022): 137-147

http://doi.org/10.17576/jsm-2022-5101-11

\title{
Catalytic Degradation of Chlorinated Lignin in Pulp Bleaching Wastewater over Immobilized Laccase
}

(Degradasi Katalitik Lignin Berklorin dalam Air Buangan Pelunturan Pulpa pada Lakase Pegun)

\author{
XUE-FeI ZHOU*
}

\section{ABSTRACT}

The aim of this study was to use molecular sieves (NaY, MCM-48, SSZ-13) and graphene oxide (GO) as supports to immobilize laccase to increase its activity and stability. A series of characterization of immobilized laccases against kinetic parameter and stability were carried out, and it was showed that the GO-immobilized laccase (Lac/GO) was better than molecular sieve-immobilized laccases (Lac/NaY, Lac/MCM, Lac/SSZ) in terms of activity and stability test using ABTS (2,2'-azino-bis(3-ethylbenzothiazoline-6-sulfonic acid)) as substrate. The impacts of enzymatic catalysis on degradation of chlorinated lignin from pulp bleaching wastewater were studied through the structural characterization with ${ }^{31} P$-NMR. Lac/GO was able to perform the most extensive oxidation of the chlorinated lignin, as demonstrated by the increase of carboxyl groups and the decrease of aliphatic hydroxyl groups. Noteworthy, significant degradation of condensed lignin substructures occurred during Lac/GO catalyzed oxidation of chlorinated lignin was observed, while the content of phenolic hydroxyl groups of chlorinated lignin substantially increased due to the cleavage of $\beta$ O-4 bonds compared to molecular sieve-immobilized laccases. It was also proved that catalytic degradation using Lac/GO as a biocatalyst is the effective method to reduce pollution load of pulp bleaching wastewater. The maximum degradation of chlorinated lignin in pulp bleaching wastewater was achieved with the degradation rate of chlorinated lignin of $88.6 \%$ at $5.0 \mathrm{~g} / \mathrm{L} \mathrm{Lac} / \mathrm{GO}$ dose, $50^{\circ} \mathrm{C}, 4 \mathrm{~h}, \mathrm{pH} 5.0$. The removal of COD, TOC, and colour was $86.2,85.8$ and $92.2 \%$, respectively.

Keywords: Biocatalysis; chlorinated lignin; degradation; laccase; pulp bleaching wastewater

ABSTRAK

Tujuan kajian ini adalah untuk menggunakan saringan molekul (NaY, MCM-48, SSZ-13) dan grafin teroksida (GO) sebagai sokongan terhadap lakase pegun untuk meningkatkan aktiviti dan kestabilan. Beberapa pencirian kepada lakase pegun terhadap parameter kinetik dan kestabilan telah dijalankan dan keputusan pencirian menunjukkan bahawa GO - lakase pegun (Lac/GO) adalah lebih baik jika dibandingkan dengan saringan molekul - lakase pegun (Lac/NaY, Lac/MCM, Lac/SSZ) dari segi ujian aktiviti dan kestabilan menggunakan ABTS (2,2'-azino-bis(3-ethylbenzothiazoline6-asid sulfonik)) sebagai substrat. Kesan daripada pemangkinan enzim pada degradasi lignin berklorin daripada air buangan pelunturan pulpa telah dikaji melalui pencirian struktur menggunakan ${ }^{31} P$-NMR. Lac/GO dapat membuat proses pengoksidaan yang paling ekstensif untuk lignin berklorin, seperti yang ditunjukkan daripada peningkatan kumpulan karboksil dan pengurangan kumpulan hidroksil alifatik. Degradasi bererti daripada substruktur lignin mampat telah berlaku ketika pemangkinan pengoksidaan Lac/GO daripada lignin berklorin telah diperhatikan, manakala kandungan kumpulan hidroksil fenol daripada lignin berklorin telah meningkat secara mendadak disebabkan pembelahan ikatan $\beta-O-4$ jika dibandingkan dengan penggunaan saringan molekul - lakase pegun. Kajian ini juga membuktikan bahawa degradasi pemangkinan menggunakan Lac/GO sebagai katalisis biopemangkin merupakan kaedah yang berkesan untuk menurunkan pencemaran yang disebabkan daripada air buangan pelunturan pulpa. Degradasi maksimum lignin berklorin dalam air buangan pelunturan pulpa telah dicapai dengan kadar degradasi lignin berklorin pada $88.6 \%$ pada dos $5.0 \mathrm{~g} / \mathrm{L} \mathrm{Lac} / \mathrm{GO}, 50^{\circ} \mathrm{C}, 4 \mathrm{jam}$, pH 5.0. Penyingkiran COD, TOC dan warna masing-masing adalah 86.2, 85.8 dan $92.2 \%$.

Kata kunci: Air buangan pelunturan pulpa; biopemangkin; degradasi; lakase; lignin berklorin 


\section{INTRODUCTION}

Various chlorinated lignins are important pollutants. They are highly toxic and hardly biodegradable. Chlorinated lignin is generally formed as by-products during pulp bleaching with chlorine-containing bleaching agents. The pulp bleaching wastewater is discharged into the aquatic environment owing to several anthropogenic activities, which may bring about serious pollution to the water body (Haq et al. 2020). Chlorinated lignin and its derived products are the main constituents of the pulp bleaching wastewater, and their toxicity may account for more than $50 \%$ of the total toxicity (Chaparro \& Rueda-Bayona 2020). Consequently, in order to solve the problem of water pollution, it is far necessary to increase the degradation and removal of chlorinated lignin from pulp bleaching wastewater. However, completely decomposing chlorinated lignin for treatment of the pulp bleaching wastewater is still a challenge. Naturally, lignin is a complex aromatic polymer consisting of various $\mathrm{C}-\mathrm{O}$ and $\mathrm{C}-\mathrm{C}$ bonds and functional groups and has a three-dimensional structure, which make lignin resistant towards the physico-chemical and biological degradation (Hita et al. 2018). Meanwhile, some physico-chemical methods have been widely used for the removal of lignin from pulp bleaching wastewater such as filtration (Kamali et al. 2019), coagulation and precipitation (Zhang et al. 2010), adsorption, reverse osmosis (Dube \& MacLatchy 2000), advance oxidation process (Abedinzadeh et al. 2018), and ozonation (Mainardis et al. 2020). But these conventional treatment processes are seldom efficacious for the sufficient degradation of chlorinated lignin from pulp bleaching wastewater. Moreover, biological method is another practical choice for chlorinated lignin and color removal in pulp bleaching wastewater. Biological wastewater treatment processes employed fungi, bacteria and enzyme as a one-step treatment and/or amalgamation of various physicochemical techniques. Compared with other methods, biological process in wastewater treatment is regarded as cost-effective and eco-friendly (Buntic et al. 2019). The decomposition of lignin is generally done by white-rot fungi belonging to Basidimycotina and few to Ascomycotina. White-rot fungi usually produce three mains extracellular ligninolytic enzymes, which are lignin peroxidase (LiP), manganese peroxidise ( $\mathrm{MnP}$ ) and laccase (Lac) (Bari et al. 2020). LiP, MnP and Lac play a crucial role in lignin degradation while Lac have been conferred as a best ligninase in pulp bleaching, degradation of environmental pollutants, industrial wastewater treatment, dye decolorization, and biological sensing (Singh \& Gupta 2020).
Furthermore, the native laccase is very sensitive on the environmental conditions. This is important factor that influence the application of laccase as a biocatalyst in industry. Thus, the immobilization onto solid support is a preferred process, which improve catalytic properties, retention activities, thermal and storage stabilities as well as reusabilities of laccase. Up to now, materials of various origin, silica and other inorganic oxides, minerals, carbon-based materials, biopolymers and synthetic polymers, have been used as supports to immobilize laccase (Aggarwal et al. 2020). GO is a chemically modified graphite containing oxygen functional groups such as epoxides, alcohols, and carboxylic acids, which is characterized with high chemical, thermal and mechanical stability, porous structure. Owing to these characteristics, GO is used in various chemical processes (Iakunkov et al. 2020). There are only few reports concerning the immobilization of laccase onto GO. Mahmoodi and Saffar-Dastgerdi (2020) used GO as a support for the immobilization of laccase. The obtained biocatalyst was used for the degradation of organic pollutant. Other research groups (Kashefi et al. 2019a; Samak et al. 2018) immobilized laccase onto GO to increase the degradation of dyes from effluents. In turn, the removal of bisphenol and catechol substrates by GO-immobilized laccase was reported by Pang et al. (2015), in which the laccase was immobilized into GO. A study in which synthesized GO magnetic nanocomposite was used as a support for laccase was reported in 2019 (Kashefi et al. 2019b). The results showed that the obtained laccase-GO magnetic nanocomposite system was stable and significant in enzymatic activity.

In this paper, GO was used as a support for the immobilization of laccase from Trametes versicolor. Laccase was immobilized using mixing method. An important aspect of this study was the evaluation of the influence of laccase immobilization on the degradation of chlorinated lignin from pulp bleaching wastewater. Pulp bleaching wastewater treatment was also researched.

\section{MATERIALS AND METHODS}

\section{PULP BLEACHING WASTEWATER}

The pulp bleaching wastewater was collected from a secondary sedimentation tank effluent in a pulp mill using CEH bleaching process for bagasse kraft pulp (C, chlorination; E, alkaline extraction; $\mathrm{H}$, hypochlorite), located in Yunnan, China. For the study, wastewater sample was filtered to remove suspended particles and stored at $4{ }^{\circ} \mathrm{C}$ until use. The $\mathrm{pH}, \mathrm{COD}$ (chemical oxygen demand), 
TOC (total organic carbon), colour and chlorinated lignin concentration of the wastewater are 8.06, 348.2, 135.7, 24.6 and $0.14 \mathrm{mg} / \mathrm{L}$, respectively.

\section{CHLORINATED LIGNIN FROM PULP BLEACHING WASTEWATER}

The pulp bleaching wastewater was vacuum-dried and extracted with dioxane/water (96/4, v/v) for $72 \mathrm{~h}$. The resulting solution was vacuum-dried, dissolved in acetic acid/water (9/1, v/v) and centrifuged. The supernatant fraction was added dropwise to the water. The insoluble fraction was dissolved in dichloroethane/ethanol (2/1, $\mathrm{v} / \mathrm{v}$ ) and centrifuged. The supernatant fraction was added dropwise to the anhydrous diethyl ether. The precipitate was washed with anhydrous diethyl ether twice and vacuum-dried to obtain the purified chlorinated lignin, used for treatment by enzyme.

\section{MATERIALS AND CHEMICALS}

The following chemicals and materials were used: n-butanol (HPLC grade, Sinopharm Chemical Reagent Co. Ltd., China); phosphate buffer saline (PBS, 99.0\%, Sinopharm Chemical Reagent Co. Ltd., China); coomassie brilliant blue (CBB, 99.0\%, Sinopharm Chemical Reagent Co. Ltd., China); 2,2'-azino-bis(3-ethylbenzothiazoline6-sulfonic acid) (ABTS, 99.0\%, Sigma-Aldrich); laccase (Lac, Trametes versicolor, powder, light brown, $23.1 \mathrm{U} / \mathrm{mg}$, Sigma-Aldrich); tetrahydrofuran (THF, chromatography grade, Sigma-Aldrich); 2-chloro-4,4,5,5-tetramethyl1,3,2-dioxaphospholane (TMDP, 99.8\%, Sigma-Aldrich); cyclohexanol (chromatography grade, Sigma-Aldrich); $\mathrm{CDCl}_{3}(99.8 \%$ atom D, Sigma-Aldrich); graphene oxide (GO, 99.0\%, Sinopharm Chemical Reagent Co. Ltd., China); molecular sieve (NaY, MCM-48, SSZ-13; 99.0\%, Sinopharm Chemical Reagent Co. Ltd., China); All other materials and chemicals (Sinopharm Chemical Reagent Co. Ltd., China) used in this work were of commercially available reagent grade and were used as received.

Milli-Q-Plus ultrapure water was used in all experiments.

\section{LACCASE IMMOBILIZATION}

The mixture containing laccase (1.2 g/L), PBS solution (20 mL, $50 \mathrm{mM}, \mathrm{pH} 4.5)$ and support (GO, MCM-56, SSZ-106, NaY) was put into a conical beaker. Then, the immobilization was performed in a rotary shaker (100 rpm) at $25^{\circ} \mathrm{C}$ for $4 \mathrm{~h}$. After that, the resulting support was rigorously washed with ultrapure water to wash away any loosely-bound laccase. The amount of immobilized laccase was determined as the difference between the initial amount of laccase and the final laccase concentration in the mixture before and after immobilization, respectively, with CBB method (Wang et al. 2007). FTIR (cm-1 ${ }^{-1} \mathrm{KBr}$ ): O-H, 3493; -NH , 3401; -COOH, 1716; N-H, 1512/1640; C-H, 1366; C-O-C, 1102. Enzyme activity: (1) $\mathrm{Lac} / \mathrm{GO}, 188.3 \mathrm{U} / \mathrm{g}_{\mathrm{GO}}$; (2) $\mathrm{Lac} / \mathrm{MCM}, 142.7 \mathrm{U} / \mathrm{g}_{\mathrm{MCM}}$; (3) $\mathrm{Lac} / \mathrm{SSZ}, 117.4 \mathrm{U} / \mathrm{g}_{\mathrm{SSZ}}$; (4) Lac/NaY, $86.5 \mathrm{U} / \mathrm{g}_{\mathrm{NaY}} S_{\mathrm{BET}}$ : (1) $\mathrm{GO}, 372.5 \mathrm{~m}^{2} / \mathrm{g}$; Lac/GO, $334.6 \mathrm{~m}^{2} / \mathrm{g}$; (2) MCM-56, $258.1 \mathrm{~m}^{2} / \mathrm{g}$; Lac/MCM, $203.7 \mathrm{~m}^{2} / \mathrm{g}$; (3) SSZ-106, 216.8 $\mathrm{m}^{2} / \mathrm{g}$; Lac/SSZ, $165.3 \mathrm{~m}^{2} / \mathrm{g}$; (4) NaY, $157.8 \mathrm{~m}^{2} / \mathrm{g}$; Lac/NaY, $102.6 \mathrm{~m}^{2} / \mathrm{g} . D_{\mathrm{BET}}$ : (1) GO, $9.5 \mathrm{~nm}$; Lac/GO, $6.7 \mathrm{~nm}$; (2) MCM-56, $5.6 \mathrm{~nm}$; Lac/MCM, $2.8 \mathrm{~nm}$; (3) SSZ-106, 5.2 nm; Lac/SSZ, 2.6 nm; (4) NaY, $4.7 \mathrm{~nm}$; Lac/NaY, $2.2 \mathrm{~nm}$.

\section{DETERMINATION OF ENZYME ACTIVITY FREE ENZYME ACTIVITY}

$1 \mathrm{~mL}$ of Laccase solution $(0.0004 \mathrm{mg} / \mathrm{mL})$ was added into $1 \mathrm{~mL}$ of PBS buffer (pH 2.5-8.0), and $1 \mathrm{~mL}$ of ABTS solution $(1.0 \mathrm{mM})$ was added. The reaction was carried out at $25-85{ }^{\circ} \mathrm{C}$ for $3 \mathrm{~min}$ and then was stopped by ice bath. After centrifugation the absorbance was measured at $\lambda=420 \mathrm{~nm}$, using a Jasco V-750 spectrophotometer (Japan). The laccase activity was calculated using the mixture containing the pre-inactivated laccase as the control. One unit of activity was defined as $1 \mu \mathrm{mol}$ of ABTS oxidized per minute $\left(\mathrm{U} / \mathrm{g}_{\text {laccase }}\right)$.

\section{IMMOBILIZED ENZYME ACTIVITY}

The oxidation of ABTS was used as a model reaction. The activity of immobilized laccase was tested by adding the immobilized laccase $(2 \mathrm{mg}$ ) into $2.5 \mathrm{~mL}$ of PBS solution (pH $2.5-8.0$ ), and $2.5 \mathrm{~mL}$ of ABTS solution (1.0 mM) was added. After the reaction was carried out at $25-85$ ${ }^{\circ} \mathrm{C}$ for $5 \mathrm{~min}$, the oxidation was stopped by ice bath. After centrifugation the absorbance was measured at $\lambda=420 \mathrm{~nm}$, using a Jasco V-750 spectrophotometer (Japan). After centrifugation the absorbance was determined at $420 \mathrm{~nm}$. The apparent activity $\left(\mathrm{U} / \mathrm{g}_{\text {support }}\right)$ was then calculated.

\section{DETERMINATION OF THE EFFECTIVENESS OF IMMOBILIZATION OF LACCASE}

The Michaelis-Menten constant $\left(K_{\mathrm{m}}\right)$ can be refer in (1) is an important kinetic parameter that reflect the effectiveness of the immobilization process. The $K_{\mathrm{m}}$ value for free and immobilized laccases, was determined using ABTS as substrate at different concentrations (0.01-0.05 mM) in PBS buffer. According to the method described in Determination of Enzyme Activity section, 
the absorbance was measured at $\lambda=420 \mathrm{~nm}$. The absorbance change $(\Delta A)$ was recorded at 10-s intervals. The initial reaction velocity with respect to enzyme was then obtained by plotting the $\Delta A$ and the reaction time $(t)$. The $K_{\mathrm{m}}$ value of the free and immobilized laccase was calculated based on the Hanes-Woolf plot can be refer in (2) (Khabiri et al. 2020):

$$
\begin{gathered}
v=V_{\max } \frac{S(t)}{K_{m}+S(t)} \\
\frac{1}{v}=\frac{K_{m}}{V_{\max }} \times \frac{1}{[S]}+\frac{1}{V_{\max }}
\end{gathered}
$$

where $v$ is the initial reaction velocity with respect to enzyme; $V_{\max }$ is the maximum reaction velocity; $S(t)$ is the concentration of the substrate; and $K_{\mathrm{m}}$ is the Michaelis constant.

The most important parameters describing immobilized enzyme are thermal and chemical stability. The thermal stability was measured at temperature range of $25-70{ }^{\circ} \mathrm{C}$ at $\mathrm{pH} 4$ and chemical stability in a $\mathrm{pH}$ range of 3-7 at $25^{\circ} \mathrm{C}$ in ABTS solution. Additionally, the reusability of the immobilized laccase was assessed in ABTS solution by determining the enzyme activities repeatedly after 10 cycles. All these evaluations were based on the relative activity of the highest activity according to the standard conditions cited above.

\section{CATALYTIC DEGRADATION OF CHLORINATED LIGNIN} SEPARATED FROM PULP BLEACHING WASTEWATER

The catalytic degradation of chlorinated lignin was performed in a flask. Oxygen gas was continuously bubbled into the solution during catalytic degradation. The reaction conditions were as follows. PBS buffer: $100 \mathrm{~mL}$, $\mathrm{pH}$ 5; chlorinated lignin: $100 \mathrm{mg}$; free and immobilized laccase: $10 \mathrm{U}$; ABTS: $10 \mathrm{mg}$; temperature: $50{ }^{\circ} \mathrm{C} ; 4 \mathrm{~h}$. After the reaction finished, the mixture was filtered. The filtrate was acidified with $1 \mathrm{M} \mathrm{HCl}$ to $\mathrm{pH} 2.0$, and the resulting solution was centrifuged. The precipitated chlorinated lignin was washed with $0.01 \mathrm{M} \mathrm{HCl}$ and ultrapure water, and freeze-dried for structural characterization with ${ }^{31} \mathrm{P}-\mathrm{NMR}$.

As control trials, chlorinated lignin was treated under the identical conditions in the absence of enzyme.

Structure of untreated and treated chlorinated lignin was quantitatively characterized for hydroxyl group content with ${ }^{31} \mathrm{P}-\mathrm{NMR}$ (BRUKER DRX500 NMR spectrometer) using cyclohexanol as the internal standard. Prior to analysis, chlorinated lignin $(25 \mathrm{mg})$ was prederivatized with TMDP $(110 \mathrm{~mL})$ in a mixture of pyridine and deuterated chloroform $(0.6 \mathrm{~mL} ; 1.6: 1 \mathrm{v} / \mathrm{v})$ (Faleva et al. 2020).

\section{CATALYTIC TREATMENT OF PULP BLEACHING WASTEWATER FOR CHLORINATED LIGNIN DEGRADATION}

The treatment of pulp bleaching wastewater was carried out a flask. Oxygen gas was continuously bubbled into the solution during treatment. An aliquot was taken out at fixed time intervals and filtered through a Millipore syringe filter of $0.45 \mu \mathrm{m}$ for determination of COD, colour, TOC, and chlorinated lignin concentration. The treatment conditions were as follows. Pulp bleaching wastewater: $80 \mathrm{~mL}$; free and immobilized laccase: 1.0 - $8.0 \mathrm{~g} / \mathrm{L}$; ABTS: $10 \mathrm{mg}$; reaction temperature: $50{ }^{\circ} \mathrm{C}$; reaction time: 1,2 , 3,4 , and $5 \mathrm{~h} ; \mathrm{pH}$ 5.0. The assays were done thrice and good reproducibility was obtained in this work, with an experimental error being below 3\%.

Chemical oxygen demand (COD) of untreated and treated wastewater was spectrophotometrically measured at $600 \mathrm{~nm}$ with a HACH-model DRB 200A using a closed reflux colorimetric method (APHA 2017). Colour of untreated and treated wastewater was measured at $455 \mathrm{~nm}$ with a HACH-MODEL DR2010 spectrophotometer. Results were expressed in $\mathrm{mg}$ Pt$\mathrm{Co} / \mathrm{L}$. Total organic carbon (TOC) of untreated and treated wastewater was measured with a ION ICS-model 1555B using a high temperature oxidation method.

The concentration of chlorinated lignin in wastewater could be measured at $280 \mathrm{~nm}$ with UV method due to its low content in waste water (Oliveira et al. 2009). The calculation was carried out according to $(3)$ :

$$
c=\frac{A}{a b}
$$

where $c$ is the chlorinated lignin concentration in wastewater $(\mathrm{g} / \mathrm{L}) ; A$ is the $\mathrm{UV}$ absorbance at $280 \mathrm{~nm}$; $a$ is the absorption coefficient $(26.1 \mathrm{~L} /(\mathrm{g} \bullet \mathrm{cm}))$; and $b$ is the optical path length of cuvette $(1 \mathrm{~cm})$.

\section{RESULTS AND DISCUSSION}

\section{KINETIC PARAMETER AND STABILITY OF IMMOBILIZED} LACCASE

The values of Michaelis constant $\left(K_{\mathrm{m}}\right)$ and maximum 
reaction velocity $\left(V_{\max }\right)$ are an important measure reflecting the affinity of an enzyme to its substrate. A higher $K_{\mathrm{m}}$ value suggests a lower binding ability with respect to the substrate (Yun \& Han 2020). The values of the neat and immobilized laccases are displayed in Figure 1(a). The $K_{\mathrm{m}}$ values of the immobilized laccases (Lac/GO, $K_{\mathrm{m}}=131.4$ $\mu \mathrm{M}$; Lac/MCM, $K_{\mathrm{m}}=165.8 \mu \mathrm{M}$; Lac/SSZ, $K_{\mathrm{m}}=176.4 \mu \mathrm{M}$; $\left.\mathrm{Lac} / \mathrm{NaY}, K_{\mathrm{m}}=185.7 \mu \mathrm{M}\right)$ were lower than that of neat laccase $\left(K_{\mathrm{m}}=244.6 \mu \mathrm{M}\right), \mathrm{Lac} / \mathrm{GO}$ in particular due to its excellent porosity (See Laccase Immobilization section) (Mukundan et al. 2020), which exhibits that the laccase's affinity for binding with ABTS improved when laccase was immobilized into these supports, Lac/GO in particular due to its excellent porosity (See Laccase Immobilization section) (Mukundan et al. 2020). Furthermore, the $V_{\max }$ value of Lac/GO was highest $(92.5 \mu \mathrm{mol} / \mathrm{min})$, dramatically
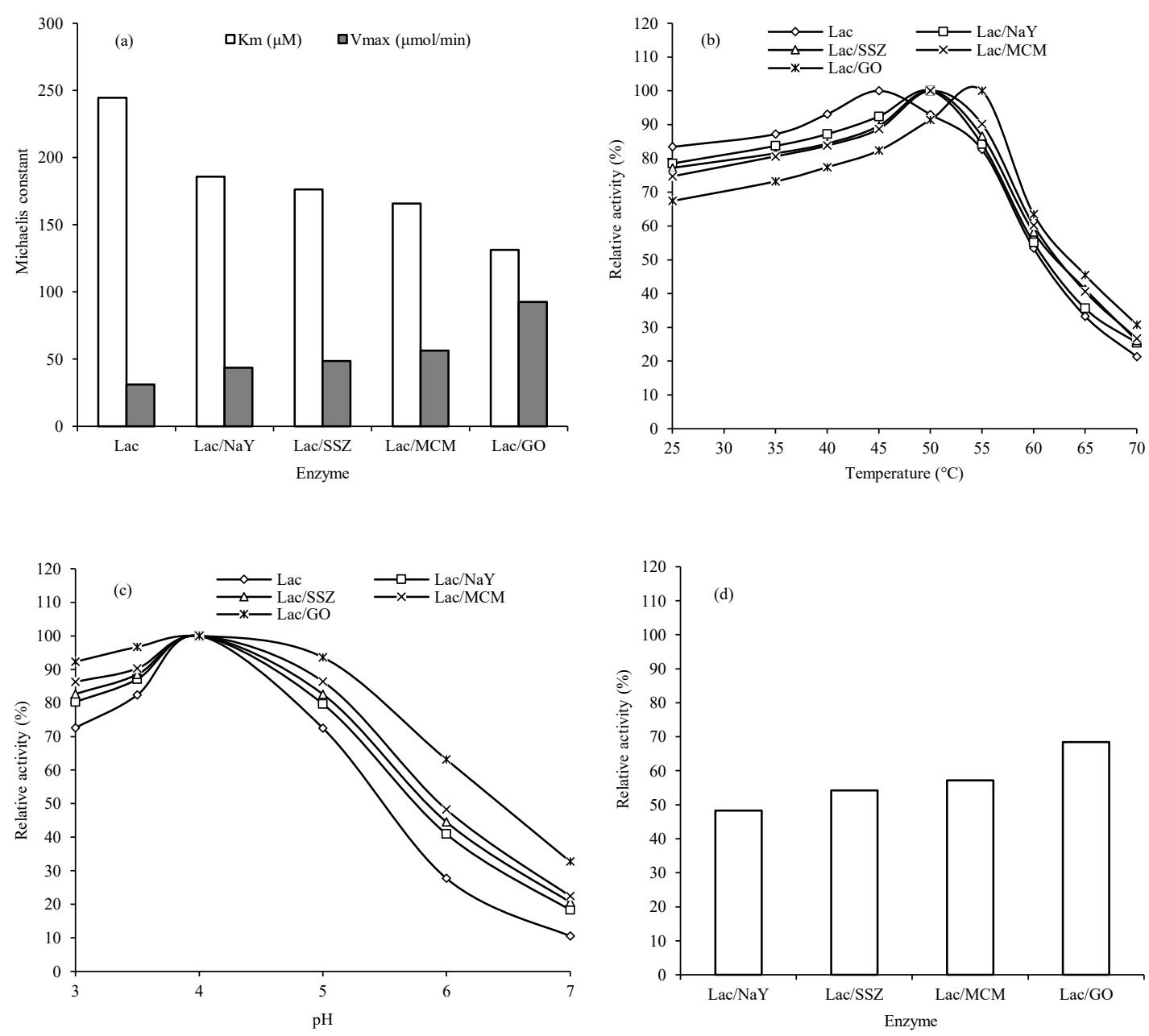

FIGURE 1. Determination of the effectiveness of immobilization of laccase: (a) Michaelis constant for free and immobilized laccase, (b) effect of temperature (pH 4.0), (c) effect of $\mathrm{pH}\left(25^{\circ} \mathrm{C}\right)$, and (d) reusability of immobilized laccase after ten repeated substrate-oxidation cycles

higher than that of neat laccase $(31.2 \mu \mathrm{mol} / \mathrm{min})$. This suggests that the Lac/GO may catalyse the reaction three times faster (Tisma et al. 2020).

Thermal stability is one of the important factor for industrial applications of laccase (Naseri et al.
2018). The heat inactivation tests were performed to evaluate the effect of immobilization on the thermal stability of laccase. The neat and immobilized laccases were incubated at different temperatures $\left(25-70{ }^{\circ} \mathrm{C}\right)$ and subsequently assayed for relative residual activity. 
Figure 1(b) demonstrates the effect of temperature on the activity of the neat and immobilized laccases in a temperature range of $25-75^{\circ} \mathrm{C}$. The Lac/GO retained $100 \%$ of its activity at the temperature of $55^{\circ} \mathrm{C}$. The Lac/ $\mathrm{MCM}, \mathrm{Lac} / \mathrm{SSZ}, \mathrm{Lac} / \mathrm{NaY}$, Lac retained 90.2, 86.6, 84.2, and $82.6 \%$, respectively. Within the range $35-55^{\circ} \mathrm{C}$ the loss of Lac/GO activity was below $30 \%$, and in particular $26.8,22.6,17.7,8.6$, and $0 \%$, respectively, at 35, 40, 45, 50 , and $55^{\circ} \mathrm{C}$. At $60{ }^{\circ} \mathrm{C}$ the loss of Lac/GO activity was $36.5 \%$. Comparison at same reaction conditions shows that the molecular sieves (Lac/MCM, Lac/SSZ, Lac/NaY) immobilized laccases established maximal activity at low temperature $\left(50{ }^{\circ} \mathrm{C}\right)$. It means the Lac/GO worked much better under the same temperature (Ivanka et al. 2020).

During the laccase immobilization, the influence of environmental $\mathrm{pH}$ on the relative enzyme activity was determined. The results are shown in Figure 1(c). The least losses of enzyme activity were observed at $\mathrm{pH} 5.0$ - the relative activity was $72.5,79.7,82.6,86.4$, and $93.6 \%$, respectively, for $\mathrm{Lac}$, Lac/NaY, Lac/SSZ, Lac/MCM, Lac/GO. The outstanding superiority was exhibited by the $\mathrm{Lac} / \mathrm{GO}$ at $\mathrm{pH} 6$, at which the $63.1 \%$ of relative enzyme activity was achieved. The porous structure of the GO and the presence of oxygen-containing groups such as carboxylic acid and phenolic hydroxyl groups on its surface, may facilitate the connection of laccase with the surface of GO with enhanced stability (Zhang et al. 2018).

In industrial applications, the reusability of immobilized laccase is a key factor for its cost-effective use (Zdarta et al. 2019). Therefore, the immobilized laccases were used as a biocatalyst in 10 cycles of ABTS oxidation reaction. As Figure 1(d) shows, the Lac/GO retained $68.4 \%$ of its initial activity at the end of the 10 th ABTS oxidation cycle, while Lac/NaY, Lac/SSZ and Lac/

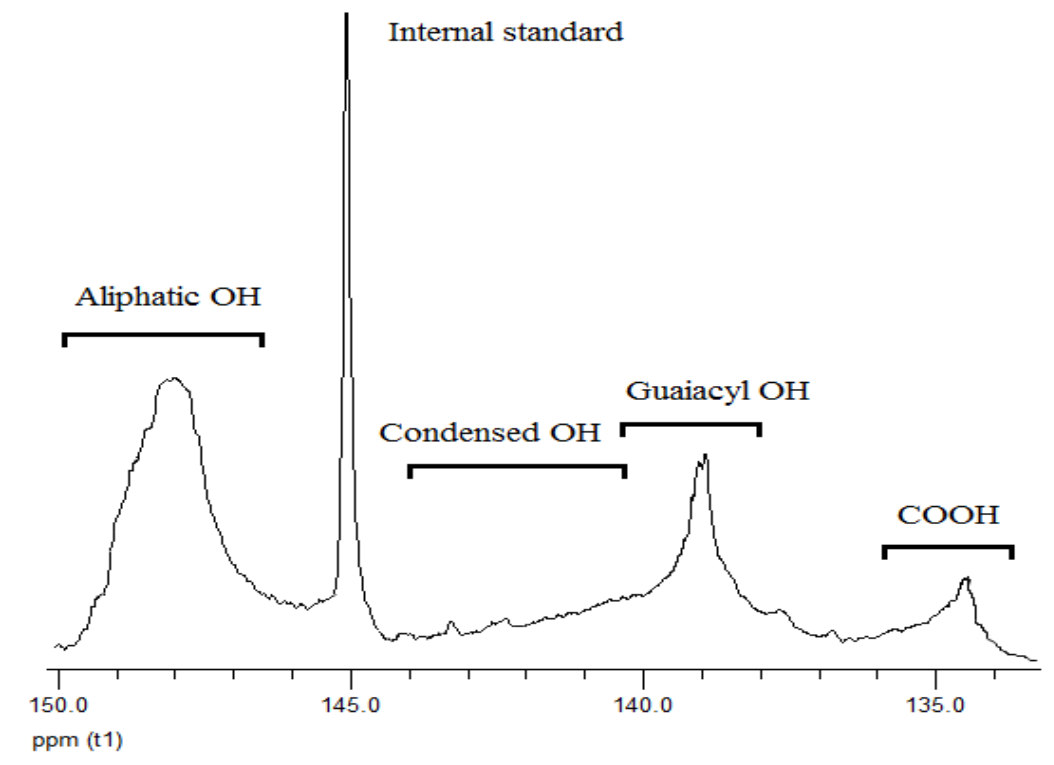

FIGURE 2. Typical ${ }^{31}$ P-NMR spectrum of chlorinated lignin after phosphitylation with TMDP

MCM retained 48.3, 54.2, and 57.2\%, respectively. In Kołodziejczak-Radzimska et al. (2020) study, mesoporous $\mathrm{Al}_{2} \mathrm{O}_{3}$ immobilized laccase preserved $60 \%$ of its initial activity after 10 cycles. Alginate/chitosan immobilized laccase retained about $50 \%$ of its initial activity (Asgher et al. 2018). In summary, the high efficiency of Lac/GO in catalytic oxidation over several cycles indicates the potential in various practical applications.

\section{CATALYTIC DEGRADATION OF CHLORINATED LIGNIN} SEPARATED FROM PULP BLEACHING WASTEWATER

After evaluating the biocatalyst kinetic parameter and stability, the oxidation of chlorinated lignin was carried out by using neat and immobilized laccases in order to assess the superiority of Lac/GO from the perspective of depolymerization pathway of chlorinated lignin. 
TABLE 1. Distribution of aliphatic, phenolic, and carboxylic hydroxy groups in chlorinated lignins before and after catalysed oxidations

\begin{tabular}{lcccc}
\hline \multirow{2}{*}{$\begin{array}{c}\text { Chlorinated lignin } \\
\text { (CL) }\end{array}$} & \multicolumn{4}{c}{ Content (mmol/g) } \\
\cline { 2 - 5 } & Aliphatic OH & Guaiacyl phenolic OH & Condensed phenolic OH & COOH \\
\hline CL & 2.85 & 1.04 & 0.46 & 0.15 \\
Control-CL & 2.82 & 1.12 & 0.44 & 0.17 \\
Lac-CL & 2.02 & 1.36 & 0.34 & 0.28 \\
Lac/NaY-CL & 1.67 & 1.55 & 0.3 & 0.34 \\
Lac/SSZ-CL & 1.61 & 1.62 & 0.27 & 0.38 \\
Lac/MCM-CL & 1.55 & 1.67 & 0.24 & 0.42 \\
Lac/GO-CL & 1.31 & 1.94 & 0.17 & 0.56 \\
\hline
\end{tabular}

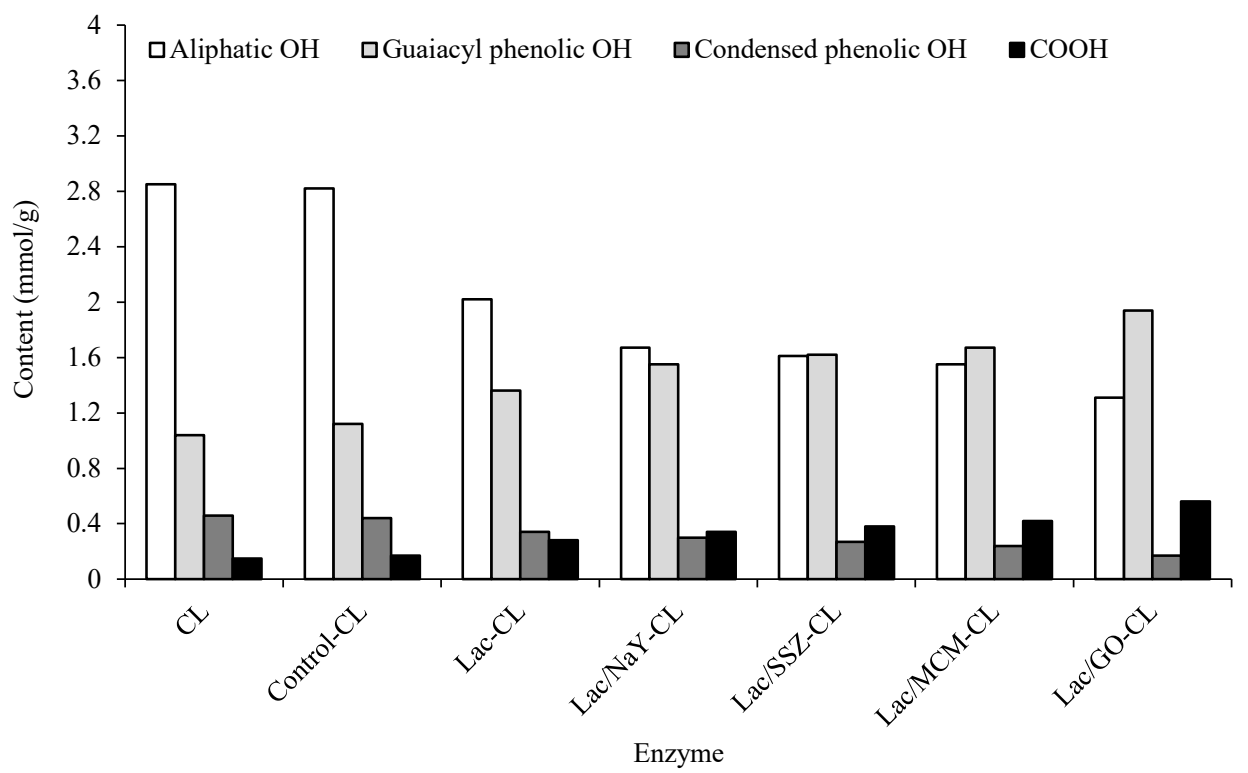

FIGURE 3. Comparison of the efficiency of neat and immobilized laccases in the oxidation of chlorinated lignin

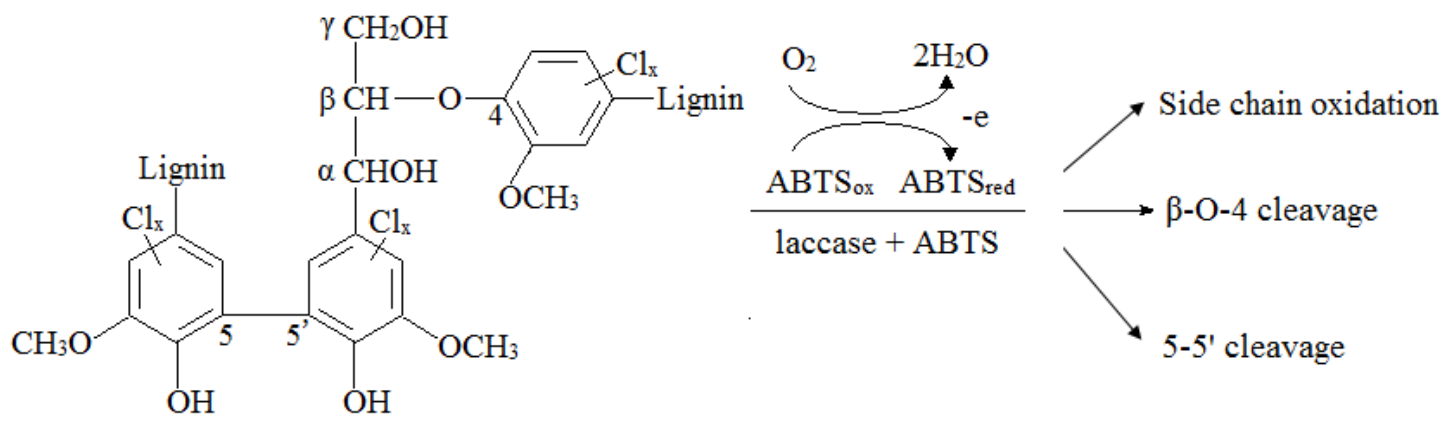

SCHEME 1. Oxidation route of chlorinated lignin 
The structural modifications induced on the chlorinated lignin were quantitatively characterized by ${ }^{31} \mathrm{P}-\mathrm{NMR}$ technique. The spectra obtained showed well resolved hydroxyl signals present within various chlorinated lignin samples. Figure 2 presents a typical ${ }^{31} \mathrm{P}-\mathrm{NMR}$ spectrum of chlorinated lignin after phosphitylation with TMDP. The detailed signals were assigned according to the reported results (Balakshin \& Capanema 2015; Zdarta et al. 2020). Table 1 reports the distribution of aliphatic, phenolic, and carboxylic hydroxy groups obtained from the spectra of chlorinated lignin before and after catalysed oxidations. Figure 3 reports the comparison of the efficiency of neat and immobilized laccases in the oxidation of chlorinated lignin. Under the experimental conditions, a decrease of aliphatic $\mathrm{OH}$ groups were evident, indicating the oxidation reactions at side-chains of chlorinated lignin (Scheme 1, side chain oxidation). The increase of $\mathrm{COOH}$ groups further verified such reaction behaviors (Jiang et al. 2017). The effect of biocatalyst mediated oxidation on chlorinated lignin was also evident on the phenolic groups' modifications. In the presence of biocatalyst an increase of guaiacyl phenolic $\mathrm{OH}$ was observed depending on the catalyst used. Such increase seems to be due to the catalytic cleavage of $\beta-O-4$ linkages (Scheme $1, \beta-O-$ 4 cleavage), further showing the side-chain oxidation reactions (Fernandez-Rodriguez et al. 2017). These biocatalysts also increased the degradation of condensed substructures (Scheme 1, 5-5' cleavage). This is crucial for extended degradation of lignin (Lambert et al. 2019). Further, the results allowed to show that the Lac/GO was able to carry out the most extensive degradation of the chlorinated lignin, as indicated by the extensive side-chain oxidation, with the increased degradation of condensed units, as shown in Figure 3.

In conclusion, the findings obtained in lignin degradation seem to be consistent with the kinetic parameter and stability. Immobilization of laccase into GO could improve its catalytic reactivity. This may be due to the reason that the GO of porosity improved the multi-point attachment with laccase and protected laccase from denaturation (Afreen et al. 2019).

\section{CATALYTIC TREATMENT OF PULP BLEACHING WASTEWATER FOR CHLORINATED LIGNIN DEGRADATION}

Based on the results presented, Lac/GO was employed to treat pulp bleaching wastewater to determine its potential value for degrading chlorinated lignin. Experiments were conducted by varying the Lac/GO dosage from $1.0-8.0 \mathrm{~g} / \mathrm{L}$. The results are illustrated in Figure 4(a). Optimal catalytic treatment of $4 \mathrm{~h}$ was observed with $5 \mathrm{~g} / \mathrm{L}$ Lac/GO dosage, in terms of the removal of COD, TOC, colour, chlorinated lignin as shown in Figure 4(a). Accordingly, further studies were performed using $5 \mathrm{~g} / \mathrm{L}$ Lac/GO dosage. The catalytic treatment of pulp bleaching wastewater was carried out by varying the reaction time from $1-5 \mathrm{~h}$ in order to assess the appropriate reaction time. As the reaction time was increased, the removal of COD, TOC, colour, chlorinated lignin increased as shown in Figure 4(b). It can also be observed that the maximum removal was achieved at the reaction time of $4 \mathrm{~h}$. Within $4 \mathrm{~h}$, the removal of COD, TOC, colour and chlorinated lignin was $86.2,85.8,92.2$, and $88.6 \%$, respectively.
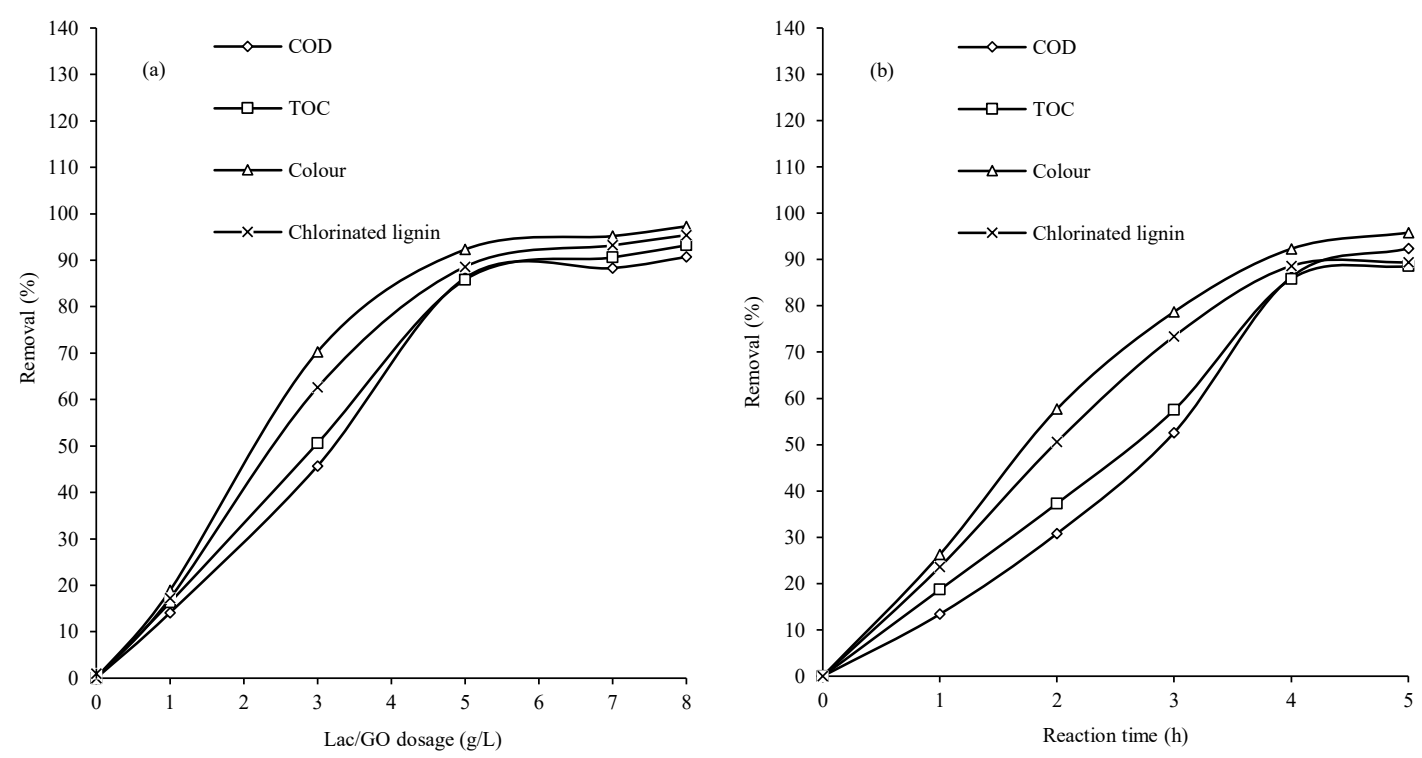

FIGURE 4. Catalytic treatment of pulp bleaching wastewater by Lac/GO: (a) effect of Lac/GO dosage (4 h), and (b) effect of reaction time ( $5 \mathrm{~g} / \mathrm{L} \mathrm{Lac} / \mathrm{GO})$ 
On the other hand, these results differ from those found by Liu and Wang (2014), who reported that the removal of COD, TOC, colour and chlorinated lignin of papermaking wastewater was, respectively, 54, 58, 90, and $85 \%$ by a surface modified magnetic silica particles immobilized laccase. In addition, Zhao et al. (2018) investigated the biocatalytic degradation of papermaking wastewater with mutant Pleurotus ostreatus laccase and reported that COD removal rate reached $85 \%$ whereas colour removal rate reached $88 \%$. The discrepancy between our results and those from reported results may be due to the difference in enzymic property, as we have discussed earlier.

\section{CONCLUSION}

Using mixing method, immobilized laccases have been successfully prepared. The results obviously exhibit the effective of laccase immobilization and GO ( $\mathrm{Lac} / \mathrm{GO})$ further improve laccase performance compared with $\mathrm{Lac} / \mathrm{NaY}, \mathrm{Lac} / \mathrm{SSZ}$ and Lac/MCM. The Lac/GO is most stable according to the analysis of dynamics and stability. Chlorinated lignin was separated from pulp bleaching wastewater and catalytically degraded. Among these biocatalysts, the $\mathrm{Lac} / \mathrm{GO}$, never used before in oxidation of chlorinated lignin from pulp bleaching wastewater, showed to be the best biocatalyst. Lac/GO is able to oxidize recalcitrant condensed lignin units most effectively. On the other hand, pulp bleaching wastewater treated with Lac/ GO did show significative improve in the level of COD, TOC, colour, chlorinated lignin. Finally, for industrial applications, $\mathrm{Lac} / \mathrm{GO}$ is a promising biocatalyst.

\section{ACKNOWLEDGEMENTS}

This research study was supported by Open Research Foundation of Henan Key Laboratory of Industrial Microbial Resources and Fermentation Technology of Nanyang Institute of Technology (HIMFT20200207), and Open Research Foundation of Fujian Provincial Key Lab of Coastal Basin Environment of Fujian Polytechnic Normal University of Fujian Province University (S1KF2007).

\section{REFERENCES}

Abedinzadeh, N., Shariat, M., Monavari, S.M. \& Pendashteh, A. 2018. Evaluation of color and COD removal by Fenton from biologically (SBR) pre-treated pulp and paper wastewater. Process Safety and Environmental Protection 116: 82-91.

Afreen, S., Idrees, D., Khera, R., Amir, M., Hassan, M.I. \& Mishra, S. 2019. Investigation of the role of central metal ion of Cyathus bulleri laccase 1 using guanidinium chloride- induced denaturation. International Journal of Biological Macromolecules 132: 994-1000.

Aggarwal, S., Chakravarty, A. \& Ikram, S. 2020. A comprehensive review on incredible renewable carriers as promising platforms for enzyme immobilization \& thereof strategies. International Journal of Biological Macromolecules 167: 962-986.

APHA. 2017. Standard Methods for the Examination of Water and Wastewater. American Public Health Association (APHA).

Asgher, M., Wahab, A., Bilal, M. \& Iqbal, H.M.N. 2018. Delignification of lignocellulose biomasses by algnatechitosan immobilized laccase produced from Trametes versicolor IBL-04. Waste and Biomass Valorization 9(11): 2071-2079.

Balakshin, M. \& Capanema, E. 2015. On the quantification of lignin hydroxyl groups with P-31 and C-13 NMR spectroscopy. Journal of Wood Chemistry and Technology 35(3): 220-237.

Bari, E., Daniel, G., Yilgor, N., Kim, J.S., Tajick-Ghanbary, M.A., Singh, A.P. \& Ribera, J. 2020. Comparison of the decay behavior of two white-rot fungi in relation to wood type and exposure conditions. Microorganisms 8(12): 1931.

Buntic, A.V., Milic, M.D., Antonovic, D.G., Siler-Marinkovic, S. \& Dimitrijevic-Brankovic, S.I. 2019. Implementation of integrated adsorption and biological process in wastewater treatment for permanent dye removal and its subsequent decontamination. Desalination and Water Treatment 169: 372-382.

Chaparro, T.R. \& Rueda-Bayona, J.G. 2020. Ecotoxicity and genetic toxicity data from a pulp mill bleaching effluent treated with anaerobic digestion and advanced oxidation process (AOP). Data in Brief 29: 105141.

Dube, M.G. \& MacLatchy, D.L. 2000. Endocrine responses of Fundulus heteroclitus to effluent from a bleached-kraft pulp mill before and after installation of reverse osmosis treatment of a waste stream. Environmental Toxicology and Chemistry 19(11): 2788-2796.

Faleva, A.V., Kozhevnikov, A.Y., Pokryshkin, S.A., Falev, D.I., Shestakov, S.L. \& Popova, J.A. 2020. Structural characteristics of different softwood lignins according to 1D and 2D NMR spectroscopy. Journal of Wood Chemistry and Technology 40(3): 178-189.

Fernandez-Rodriguez, J., Erdocia, X., Sanchez, C., Alriols, M.G. \& Labidi, J. 2017. Lignin depolymerization for phenolic monomers production by sustainable processes. Journal of Energy Chemistry 26(4): 622-631.

Haq, I., Mazumder, P. \& Kalamdhad, A.S. 2020. Recent advances in removal of lignin from paper industry wastewater and its industrial applications - A review. Bioresource Technology 312: 123636.

Hita, I., Heeres, H.J. \& Deuss, P.J. 2018. Insight into structurereactivity relationships for the iron-catalyzed hydrotreatment of technical lignins. Bioresource Technology 267: 93-101.

Iakunkov, A. \& Talyzin, A.V. 2020. Swelling properties of graphite oxides and graphene oxide multilayered materials. Nanoscale 12(41): 21060-21093. 
Ivanka, S., Albert, K. \& Veselin, S. 2010. Properties of crude laccase from Trametes versicolor produced by solid-substrate fermentation. Advances in Bioscience and Biotechnology 1(3): 208-215.

Jiang, W.K., Wu, S.B., Lucia, L.A. \& Chu, J.Y. 2017. Effect of side-chain structure on hydrothermolysis of lignin model compounds. Fuel Processing Technology 166: 124-130.

Kamali, M., Suhas, D.P., Costa, M.E., Capela, I. \& Aminabhavi, T.M. 2019. Sustainability considerations in membrane-based technologies for industrial effluents treatment. Chemical Engineering Journal 368: 474-494.

Kashefi, S., Borghei, S.M. \& Mahmoodi, N.M. 2019a. Covalently immobilized laccase onto graphene oxide nanosheets: Preparation, characterization, and biodegradation of azo dyes in colored wastewater. Journal of Molecular Liquids 276: 153-162.

Kashefi, S., Borghei, S.M. \& Mahmoodi, N.M. 2019 b. Superparamagnetic enzyme-graphene oxide magnetic nanocomposite as an environmentally friendly biocatalyst: Synthesis and biodegradation of dye using response surface methodology. Microchemical Journal 145: 547-558.

Khabiri, B., Ferdowsi, M., Buelna, G., Jones, J.P. \& Heitz, M. 2020. Simultaneous biodegradation of methane and styrene in biofilters packed with inorganic supports: Experimental and macrokinetic study. Chemosphere 252: 126492.

Kołodziejczak-Radzimska, A., Budna, A., Ciesielczyk, F., Moszyński, D. \& Jesionowski, T. 2020. Laccase from Trametes versicolor supported onto mesoporous Al2O3: Stability tests and evaluations of catalytic activity. Process Biochemistry 95: 71-80.

Lambert, E., Aguié-Béghin, V., Dessaint, D., Foulon, L., Chabbert, B., Paës, G. \& Molinari, M. 2019. Real time and quantitative imaging of lignocellulosic films hydrolysis by atomic force microscopy reveals lignin recalcitrance at nanoscale. Biomacromolecules 20(1): 515-527.

Liu, Y. \& Wang, Z. 2014. Immobilization of laccase on surface modified magnetic silica particles and its use for the papermaking wastewater. Applied Mechanics \& Materials 670-671: 267-270.

Mainardis, M., Buttazzoni, M., De, B.N., Mion, M. \& Goi, D. 2020. Evaluation of ozonation applicability to pulp and paper streams for a sustainable wastewater treatment. Journal of Cleaner Production 258: 120781.

Mahmoodi, N.M. \& Saffar-Dastgerdi, M.H. 2020. Clean laccase immobilized nanobiocatalysts (graphene oxide - zeolite nanocomposites): From production to detailed biocatalytic degradation of organic pollutant. Applied Catalysis B-Environmental 268: 118443.

Mukundan, S., Melo, J.S., Sen, D. \& Bahadur, J. 2020 Enhancement in beta-galactosidase activity of Streptococcus lactis cells by entrapping in microcapsules comprising of correlated silica nanoparticles. Colloids and Surfaces B, Biointerfaces 195: 111245.
Naseri, M., Pitzalis, F., Carucci, C., Medda, L., Fotouhi, L., Magner, E. \& Salis, A. 2018. Lipase and laccase encapsulated on zeolite imidazolate framework: Enzyme activity and stability from voltammetric measurements. ChemCatChem 10(23): 5425-5433

Pang, R., Li, M.Z. \& Zhang, C.D. 2015. Degradation of phenolic compounds by laccase immobilized on carbon nanomaterials: Diffusional limitation investigation. Talanta 131: $38-45$

Samak, N.A., Tan, Y.Q., Sui, K.Y., Xia, T.T., Wang, K.F., Guo, C. \& Liu, C.Z. 2018. CotA laccase immobilized on functionalized magnetic graphene oxide nano-sheets for efficient biocatalysis. Molecular Catalysis 445: 269-278.

Singh, D. \& Gupta, N. 2020. Microbial laccase: A robust enzyme and its industrial applications. Biologia 75(8): 1183-1193

Tisma, M., Salic, A., Planinic, M., Zelic, B., Potocnik, M., Selo, G. \& Bucic-Kojic, A. 2020. Production, characterisation and immobilization of laccase for an efficient aniline -based dye decolourization. Journal of Water Process Engineering 36: 101327

Wang, X., Li, X. \& Li, Y. 2007. A modified Coomassie Brilliant Blue staining method at nanogram sensitivity compatible with proteomic analysis. Biotechnology Letters 29: 15991603.

Yun, K.I. \& Han, T.S. 2020. Relationship between enzyme concentration and Michaelis constant in enzyme assays. Biochimie 176: 12-20.

Zdarta, J., Jankowska, K., Wyszowska, M., KijenskaGawronska, E., Zgala-Grzeskowiak, A., Pinelo, M., Meyer, A.S., Moszynski, D. \& Jesionowski, T. 2019. Robust biodegradation of naproxen and diclofenac by laccase immobilized using electrospun nanofibers with enhanced stability and reusability. Materials Science \& Engineering C-Materials for Biological Applications 103: 109789.

Zhang, J., Han, X.L., Jiang, B., Qiu, X.F. \& Gao, B.Y. 2010. A hybrid system combining self-forming dynamic membrane bioreactor with coagulation process for advanced treatment of bleaching effluent from straw pulping process. Desalination and Water Treatment 18(1-3): 212-216.

Zhang, S.T., Wu, Z.F., Chen, G. \& Wang, Z. 2018. An improved method to encapsulate laccase from Trametes versicolor with enhanced stability and catalytic activity. Catalysts 8(7): 286.

Zhao, L.H., Ma, Q.Q., Nie, F., Chen, W. \& Sun, H.J. 2018. Increasing laccase activity of white rot fungi by mutagenesis and treating papermaking wastewater. In IOP Conference Series: Earth and Environmental Science. IOP. 012053.

Henan Key Laboratory of Industrial Microbial Resources and Fermentation Technology

Nanyang Institute of Technology

473000 Nanyang

China 
Fujian Provincial Key Lab of Coastal Basin Environment Fujian Polytechnic Normal University

Fujian Province University

350300 Fuzhou

China

Faculty of Chemical Engineering

Kunming University of Science and Technology

650500 Kunming

China
*Corresponding author; email: 1gdx602@sina.com

Received: 9 January 2021

Accepted: 22 April 2021 